\title{
Kreowanie i sprzedaż oczekiwań w branży gier komputerowych
}

\section{Creating and selling expectations in the video games industry}

\author{
dr hab. Beata Stępień, prof. Uniwersytetu Ekonomicznego w Poznaniu \\ Uniwersytet Ekonomiczny w Poznaniu, Katedra Zarządzania Międzynarodowego \\ ORCID: 0000-0002-0488-1146 \\ e-mail: beata.stepien@ue.poznan.pl
}

\author{
mgr Piotr Podbielski \\ doktorant Uniwersytetu Ekonomicznego w Poznaniu
}

\begin{abstract}
Artykuł, bazując na teorii wartości oczekiwanej i współkreowanej przez konsumenta w procesie konsumpcji oraz na koncepcjach modeli biznesowych, przedstawia sposób komunikowania i monetyzacji produktu (tu: gry) dostarczanego fragmentarycznie. Głównym celem takiego działania jest pobudzenie i podtrzymanie oczekiwania ze strony konsumentów przy zapewnieniu dochodów w całym cyklu tworzenia gry. Wartość produktu końcowego jest współkreowana przez konsumentów i dostawców gier komputerowych, a propozycja wartości (value proposition) staje się jednocześnie wartością współtworzoną (value in context) i doświadczaną jeszcze przed zakupem produktu finalnego. Analiza sposobu komunikacji oraz monetyzacji wartości w branży gier komputerowych wzbogaca dotychczasowe rozumienie etapów tworzenia propozycji wartości i wartości współkreowanej w procesie konsumpcji, opisywanych dotychczas jako następujące (a nie współwystępujące) etapy w ramach logiki S-D (service-dominant logic), zaproponowanej i rozwijanej przez Vargo i Luscha (2004, 2008, 2016).
\end{abstract}

\section{Keywords}

gry komputerowe, model biznesowy, wartość dla konsumenta, wartość oczekiwana, wartość doświadczana, monetyzacja wartości

\begin{abstract}
Using the concepts of consumer expected value, value cocreation in the consumption process and business models, the article explains how a certain product: a video game, is communicated and monetized while being delivered in a fragmentary way. The aim of such an action is to arouse and maintain the state of expectation within gamers while generating income at different stages of the video game development cycle. The value of the end product is cocreated by the consumers and video game developers and publishers, whereas the value proposition becomes both value in context and value experienced even before the acquisition of the end product. The analysis of how value in the video game industry is communicated and monetized expands the existing understanding of designing value proposition and value co-creation during the consumption as coexisting stages in service - dominant logic (Vargo and Lusch, 2004, 2008, 2016).
\end{abstract}

\section{Slowa kluczowe}

video games, business model, value for customer, expected value, experienced value, value monetization

JEL: M31

Str. $25-36$ 


\section{Bibliografia}

Akaka, M. A. i Chandler, J. D. (2011). Roles as Resources: A Social Roles Perspective of Change in Value Networks. Marketing Theory, 11(3), 243-260. https://doi.org/10.1177/1470593111408172

Ars Technica. (2014). Introducing Steam Gauge: Ars reveals Steam's most popular games. Pozyskano z https:// arstechnica.com/gaming/2014/04/introducing-steam-gauge-ars-reveals-steams-most-popular-games/

Dziewanowska, K. (2018). Proces współtworzenia wartości - konceptualizacja i wybrane modele badawcze. Studia Oeconomica Posnaniensia, 6(6), 76-86. https://doi.org/10.18559/SOEP.2018.6.6

Esposito, N. (2005). A Short and Simple Definition of What a Videogame Is. Pozyskano z http://www.utc.fr/ $\sim$ nesposit/publications/esposito2005definition.pdf

Galyonkin, S. (2018). Steam in 2017. How Steam Direct, PUBG and the rise of China affected the biggest PC gaming marketplace in 2017. Pozyskano z https://galyonk.in/steam-in-2017-129c0e6be260

Glucksman, M. (2017). The Rise of Social Media Influencer Marketing on Lifestyle Branding: A Case Study of Lucie Fink. Elon Journal of Undergraduate Research in Communications, 8(2), 77-87. Pozyskano z https://www.elon.edu/u/ academics/communications/journal/wp-content/uploads/sites/153/2017/12/08_Lifestyle_Branding_Glucksman.pdf

Henderson, P. W. i Peterson, R. A. (1992). Mental Accounting and Categorization. Organizational Behavior and Human Decision Processes, 51(1), 92-117. https://doi.org/10.1016/0749-5978(92) 90006-S

Holbrook, M. B. (2006), Consumption Experience, Customer Value, and Subjective Personal Introspection: An Illustrative Photographic Essay. Journal of Business Research, 59(6), 714-725. https://doi.org/10.1016/j.jbusres.2006.01.008

Jabłoński, M. M. (2013). Kształtowanie modeli biznesu w procesie kreacji wartości przedsiębiorstw. Warszawa: Difin.

Kotaku. (2014). We're Buying More PC Games Than We Can Play. Pozyskano z https://kotaku.com/were-buying-more-pcgames-than-we-can-play-1493-402988

Leonard, T. C. (2008). Richard H. Thaler, Cass R. Sunstein, Nudge: Improving Decisions about Health, Wealth, and Happiness. Constitutional Political Economy, 19(4), 356-360. https://doi.org/10.1007/s10602-008-9056-2

Lightspeed Venture Partners. (2008). 29 business models for games. Pozyskano z https://lsvp.wordpress.com/2008/07/02/29business-models-for-games/

Livingston, I. J., Nacke, L. E. i Mandryk, R. L. (2011a). The Impact of Negative Game Reviews and User Comments on Player Experience. Pozyskano z https://www.researchgate.net/publication/228466586_The_Impact_of_Negative_ Game_Reviews_and_User_Comments_on_Player_Experience

Livingston, I. J., Nacke, L. E. i Mandryk, R. L. (2011b). Influencing Experience: The Effects of Reading Game Reviews on Player Experience. Pozyskano $\mathrm{z}$ https://www.researchgate.net/publication/220851176_Influencing_Experience_ The_Effects_of_Reading_Game_Reviews_on_Player_Experience

Marchand, A. i Hennig-Thurau, T. (2013). Value Creation in the Video Game Industry: Industry Economics, Consumer Benefit, and Research Opportunities. Journal of Interactive Marketing, 27, 141-157. Pozyskano z https://www. researchgate.net/publication/255995598_Value_Creation_in_the_Video_Game_Industry_Industry_Economics_Consu mer_Benefits_and_Research_Opportunities/download

Mazur, J. i Zaborek, P. (2014). Validating DART Model. International Journal of Management and Economics, 44(1), 106125. https://doi.org/10.1515/ijme-2015-0012

Newzoo. (2018). Mobile Revenues Account for More Than 50\% of the Global Games Market as It Reaches \$137.9 Billion in 2018. Pozyskano z https://newzoo.com/insights/articles/global-games-market-reaches-137-9-billion-in-2018-mobilegames-take-half/

Ng, I. C. i Smith, L. A. (2012). An Integrative Framework of Value. W: Special Issue - Toward a Better Understanding of the Role of Value in Markets and Marketing (s. 207-243). Emerald Group.

Oleś, P. (2002). Z badań nad wartościami i wartościowaniem: niektóre kwestie metodologiczne. Roczniki Psychologiczne, (5), 53-75.

Osterwalder, A. i Pigneur, Y. (2010). Business Model Generation: A Handbook for Visionaries, Game Changers, and Challengers. John Wiley \& Sons.

Pura, M. (2005). Linking Perceived Value and Loyalty in Location - Based Mobile Services. Managing Service Quality, 15, 509-538. https://doi.org/10.1108/09604520510634005

Rogoziński, K. (2011). Zarządzanie wartościa z klientem. Warszawa: Wolters Kluwer.

Ruggles, C., Wadley, G. i Gibbs, M. R. (2005). Online Community Building Techniques Used by Video Game Developers. Pozyskano z https://www.researchgate.net/publication/220851262_Online_Community_Building_Techniques_Used_ by_Video_Game_Developers

Sánchez-Fernández, R. i Iniesta-Bonillo, M. Á. (2006). Consumer Perception of Value: Literature Review and a New Conceptual Framework. Journal of Consumer Satisfaction, Dissatisfaction and Complaining Behavior, (19), 40-58.

Sheth, J., Newman, B. I. i Gross, B. L. (1991). Consumption Values and Market Choices. Theory and Application. Cincinnati: South-Western Publishing. 
Stępień, B. (2017). In Search of Apprehending Customers' Value Perception. International Journal of Management and Economics, 53(1), 99-117. https://doi.org/10.1515/ijme-2017-0007

Stępień, B. (2019, w druku). Wartość luksusu. Perspektywa konsumentów i przedsiębiorstw. Warszawa: PWE.

Stuart, K. (2013). Gamer Communities: The Positive Side. Pozyskano z https://www.theguardian.com/technology/gamesblog/ 2013/jul/31/gamer-communities-positive-side-twitter

Sweeney, J. C. i Soutar, G. N. (2001), Consumer Perceived Value: The Development of a Multiple Item Scale, Journal of Retailing, 77, 203-220. https://doi. org/10.1016/S0022-4359 (01) 00041-0

Thaler, R. (1985). Mental Accounting and Consumer Choice. Marketing Science, 4(3), 199-214. https://doi.org/10.1287/ mksc.4.3.199

Thaler, R. (1999). Mental Accounting Matters. Journal of Behavioral Decision Making, 12(3), 183-206. https://doi.org/ 10.1002/(SICI)1099-0771(199909)12:3<183::AID-BDM318>3.0.CO;2-F

Vargo, S. L. i Lusch, R. F. (2004). Evolving to a New Dominant Logic for Marketing. The Journal of Marketing, 68, 1-17. https://doi.org/10.1509/jmkg.68.1.1.24036

Vargo, S. L. i Lusch, R. F. (2008). Service-dominant Logic: Continuing the Evolution. Journal of the Academy of Marketing Science, 36(1), 1-10. https://doi. org/10.1007/s11747-007-0069-6

Vargo, S. L. i Lusch, R. F. (2016). Institutions and Axioms: An Extension and Update of Service-dominant Logic. Journal of the Academy of Marketing Science, 44(1), 5-23. https://doi.org/10.1007/s11747-015-0456-3

Windows Central. (2017). The Major Differences between „Indie” and „AAA” Video Games. Pozyskano z https://www. windowscentral.com/indie-vs-aaawhich-type-game-you

Woodall, T. (2003). Conceptualising „Value for the Customer”: An Attributional, Structural and Dispositional Analysis. Academy of Marketing Science Review, 12, 1-42.

Zeithaml, V. A. (1988). Consumer Perceptions of Price, Quality, and Value: A Means-end Model and Synthesis of Evidence. The Journal of Marketing, 52, 2-22. https://doi.org/10.1177/002224298805200302 